\title{
ASEAN and the BRI: The Utility of Equidistant Diplomacy with China and the US
}

\author{
Hiro Katsumata and Shingo Nagata
}

\begin{abstract}
The aim of the present study is to shed light on the diplomatic achievements of the Association of Southeast Asian Nations (ASEAN), by exploring the way in which it has dealt with the Belt and Road Initiative (BRI) implemented by China. ASEAN is little more than an association of minor powers with insignificant military and economic capabilities. However, in its dealings with the BRI, it has proactively advanced its own interests by skillfully conducting equidistant diplomacy with China and the US, without becoming too remote from or too close to either one of them, thereby reaping benefits from its favorable relations with each of them.
\end{abstract}

Keywords Belt and Road Initiative (BRI), One Belt One Road, Association of Southeast Asian Nations (ASEAN), China, United States

\section{Introduction}

Within the large geographical area covered by China's Belt and Road Initiative (BRI), Southeast Asia occupies an important strategic location. This region has several maritime chokepoints, such as the Malacca Strait, the Sunda Strait, and the Lombok Strait, all of which are positioned on important international shipping routes connecting the Indian Ocean and the Pacific Ocean. The BRI comprises the "economic belt" stretching from the western part of China to Central Asia and Europe, and the "maritime road" extending from the coastal area of China to Southeast Asia, South Asia, the Middle East, East Africa, and Europe. Due to the geographical proximity of the Southeast Asian nations to China, the former are effectively linking the latter with more than fifty states located along this "road."

Few leaders have recognized the strategic importance of Southeast Asia more clearly than the Chinese President Xi Jinping. This is why he announced the Chinese twenty-first century Maritime Silk Road initiative at the Indonesian Parliament in October 2013, bearing in mind the major role Jakarta commonly plays in Southeast Asian affairs. This initiative eventually developed into the BRI, 
together with the Silk Road Economic Belt initiative announced in Kazakhstan one month earlier. It is also worth mentioning that, when President Xi visited Indonesia in October 2013, he officially unveiled a plan to establish the Asian Infrastructure Investment Bank (AIIB), a regional development bank meant to serve as the financial basis of the BRI.

The Association of Southeast Asian Nations (ASEAN) is the central player in this strategically important region. This association was established in 1967, against the background of the East-West confrontation at the global level and the Vietnam War at the regional level, by five Southeast Asian nations, namely, Indonesia, Malaysia, Singapore, Thailand, and the Philippines. Today it has developed into an association of ten nations, including Brunei, Vietnam, Laos, Myanmar, and Cambodia. Remarkably, it has become an important player in Southeast Asia and beyond, hosting mega-regional forums such as the ASEAN Regional Forum (ARF), the Post-Ministerial Conference (PMC), the ASEAN Plus Three (APT), and the East Asia Summit (EAS). Nevertheless, after all, it is little more than an association of minor powers with insignificant military and economic capabilities. In the competitive world of international relations, minor powers are usually at the mercy of major powers and unable to advance their own interests by their own means. The reality of international relations is that, in the words of Thucydides who studied the history of the Peloponnesian War, the strong do what they can and the weak suffer what they must (Strassler 1996, 352). However, a careful assessment of ASEAN's dealings with the BRI reveals that this kind of common understanding is not always accurate.

The aim of the present study is to shed light on ASEAN's diplomatic achievements by exploring three questions concerning the BRI. The first section explores what the BRI is, in the context of global geopolitics. It argues that the BRI is something which constitutes a core element of the geopolitical rivalry between China and the United States today. The second section examines what the BRI is for ASEAN. It maintains that the BRI is something which prompts the Southeast Asian association to tackle a major task of conducting equidistant diplomacy with Beijing and Washington. The third section explores the way in which ASEAN has dealt with the BRI. It holds that this association has basically committed itself to the BRI; yet, at the same time, it has been careful not to overcommit itself. Thus, while keeping a certain distance from China, it has cleverly strengthened its economic and security relations with the United States. The concluding section sums up the argument by stating that, in its dealings with the BRI, an association of minor powers in Southeast Asia has proactively advanced its own interests by skillfully conducting equidistant diplomacy with China and the United States.

Before proceeding any further, a practical issue should be mentioned: at the risk of oversimplification, the present study addresses the policies and interests of ASEAN as a single entity. This kind of approach can only be justified when the focus of analysis is on ASEAN's external relations. The members of 
this association disagree on many issues within Southeast Asia, but often share common interests when they deal with external powers, and therefore speak with one voice and act as a single "diplomatic community," so as to ensure a more significant role than any member could have played alone (Leifer 1989, 86, 152; 1995, 133).

\section{BRI in Global Geopolitics}

What is the BRI in the context of global geopolitics? In short, the BRI is something which constitutes a core element of the geopolitical rivalry between China and the United States today. There is little doubt that the rivalry between these two major powers has become intense in recent years. What is especially notable about their rivalry is the fact that its geographical scope has expanded, as the notion of the "Indo-Pacific" has been added to the lexicon of global geopolitics. This kind of development is partly driven by the implementation of the BRI by China.

The nature of the BRI can become a subject of debate. For its advocates, the $\mathrm{BRI}$ is a promising economic project, aimed at facilitating international economic exchanges for the sake of mutual benefits between China and its partners by developing infrastructure needed for such exchanges, including railroads, highways, ports, and pipelines. Thus, many countries, including those in Europe and North America, should actively participate in it and collaborate with Beijing to expand its economic scale (see, for example, Wang 2016; Li and Zheng 2019; Zhang 2019). In contrast, for its critics, it is an ill-motivated geopolitical project, aimed at expanding not only Beijing's economic roles but also its political and security presence in a broad area encompassing Southeast Asia, Central Asia, the Middle East, East Africa, and Europe. Hence, the world has every reason to worry about it, and the European and North American countries in particular should implement various measures to prevent its successful development (see, for example, Kliman and Grace 2018; The Economist 2018; Shabir 2018; for mixed views, see Tekdal 2018; Gong 2019).

In any case, it is fair to say that the BRI is indeed an important component of China's global strategy, regardless of whether its nature is benign or malign. This country is certainly looking at a broad geographical area, and its focus extends as far as East Africa. At the summit meeting of the Forum on ChinaAfrica Cooperation in September 2018, President Xi underlined the significance of Beijing's infrastructure projects in Africa in the context of the BRI, and made it clear that China will strengthen its commitment to Africa (Xi 2018). Notably, in January 2017, in collaboration with its local partners, China constructed a railroad in East Africa which connects Ethiopia and Djibouti. Although the latter is a small country, it faces the Gulf of Aden and occupies one of the most 
strategically important places in global geopolitics. It was in such an important place that China built its first overseas military base in August 2017.

Few countries around the world are more concerned about China's global activism than the United States. Many aspects of Beijing's BRI are incompatible with Washington's global strategy, from the viewpoint of the latter. Unsurprisingly, the geopolitical rivalry between China and the United States today has become bitter. One of the areas in which their rivalry is most serious is the Indo-Pacific, which encompasses the Indian Ocean and the Pacific Ocean. The importance of the Indo-Pacific in the BRI cannot be overemphasized because a major section of the "maritime road" runs through the Indian Ocean and the Pacific Ocean. In May 2018, Washington renamed its Pacific Command the "U.S. Indo-Pacific Command," although its area of responsibility had already included not only the Pacific Ocean but also the Indian Ocean. Washington did so, in order to manage the two maritime areas in a comprehensive way without allowing China to expand its influence there. It can be said that the Indo-Pacific has become the frontline of the rivalry between China and the United States today, partly due to its relevance to the former's BRI.

\section{ASEAN’s Task}

What is the BRI for ASEAN? In short, the BRI is something which prompts this association to tackle a major task of conducting equidistant diplomacy with China and the United States, with the aim of reaping benefits from its favorable relations with each of them. To the extent that the BRI constitutes a core element of the geopolitical rivalry between China and the United States today, it inevitably makes it difficult for ASEAN to manage its relations with both of these two major powers. For this association, it is imperative that it skillfully conduct equidistant diplomacy with them, without becoming too remote from or too close to either one of them. ${ }^{1}$

This kind of diplomatic task has always been important in post-Cold War Southeast Asia, which is marked by the presence of a number of major players, such as China, the United States, Japan, and India. ASEAN's relations with these external powers should largely be equidistant, and its relations with each of them should be neither too remote nor too close. For this association, it is simply unwise to become too remote from any of them and to lose great opportunities to get benefits from favorable relations. Becoming too remote from one is especially undesirable if it means becoming too close to another. It is unwise to become too close to any of the external powers because doing so would run the risk of becoming over-dependent on it. Needless to say, it is also unwise to build close relations with one particular external power at the expense of the association's existing relations with another. After all, only by conducting equidistant diplomacy 
with various external powers without becoming too remote from or too close to any one of them can an association of minor powers in Southeast Asia reap benefits from its favorable relations with each of them.

It is fair to say that equidistant diplomacy encompasses the strategy of hedging, which has attracted scholarly attention in the past decade or two (examples of early works include Chung 2004; Goh 2005). ASEAN's equidistant diplomacy has two dimensions: one is to maximize the benefits by maintaining favorable relations with various external powers and the other is to minimize the risk of becoming over-dependent on any of them. The hedging strategy addresses the latter dimension, in that it is all about hedging against potential risks (for a different conceptualization, see Kuik 2016).

Given its risk-minimization dimension, it can be said that equidistant diplomacy addresses ASEAN's long-term concern about external interference. Since its establishment in 1967, the association has always been concerned about the possibility of external powers interfering in Southeast Asian affairs. This is hardly surprising, bearing in mind that most of its members had been colonized by Western powers for a long time, and gained independence only in the postwar era. For ASEAN, the minimization of the risk of over-dependency through the exercise of equidistant diplomacy must be a prerequisite for preventing external interference, in that one of the possible consequences of becoming overdependent on an external power must be to allow it to interfere in Southeast Asian affairs.

The rest of this section focuses on ASEAN's policy over the last few decades toward China and the United States in turn, for a better understanding of its equidistant diplomacy with Beijing and Washington.

\section{ASEAN's Policy toward China}

From the viewpoint of ASEAN, China is a country which can easily pose a threat to regional security in Southeast Asia. It is geographically proximate to this region, and far greater than any of the nations there in terms of military power, economic potential, and the population size. Historically speaking, it has frequently worried many of the ASEAN members. To begin with, during the Cold War era, it often supported the anti-government communist factions within these members. This was a source of serious security concern for them, since they were having a hard time governing their post-independent multiethnic societies. In addition, in 1992, Beijing effectively declared ownership of many of the islands in the South China Sea by instituting its own maritime law. This inevitably exacerbated the territorial disputes between Beijing and the Southeast Asian claimants to these islands, namely, Malaysia, the Philippines, Brunei, and Vietnam. Since then, Beijing has in principle maintained a rigid attitude toward ASEAN in addressing the South China Sea disputes. To be sure, in 2002, it modified its uncompromising stance, and the two parties issued a joint declaration on appropriate conduct in the South 
China Sea in 2002 (ASEAN and China 2002a). Yet this was not a legally binding agreement, but a political declaration. To this day, the territorial disputes in the South China Sea have remained a bone of contention between the two parties.

However, over the last few decades, ASEAN has steadily strengthened its relations with China, with the aim of building win-win relations. Although Beijing can easily pose a threat to regional security in Southeast Asia, it can also bring a lot of benefits to this region. Hence, especially in the post-Cold War era, the ASEAN members have been proactive toward China. In 1990, Indonesia reestablished diplomatic relations with China, which had been severed for more than two decades since 1967. Singapore followed suit, and established official relations with Beijing in the same year. Owning to these positive developments, ASEAN invited China to attend the first meeting of the ARF in 1994, the PMC in 1996, and also the de facto first summit meeting of the APT in 1997, in the wake of the outbreak of the Asian financial crisis. Rather than excluding Beijing from these forums, the Southeast Asian association chose to engage and collaborate with it to achieve mutual benefits within these forums.

In the twenty-first century, ASEAN has further deepened and broadened its cooperative relations with China. It has concluded a series of economic agreements with Beijing, thereby promoting free trade in goods and services and also multiplying investment opportunities (ASEAN and China 2002b, 2007, 2009). With regard to the territorial disputes in the South China Sea, it has been exploring a few different ways to issue a legally binding code of conduct. Perhaps more importantly, in October 2018, the ASEAN members conducted for the first time a joint maritime exercise with Beijing. To be sure, this was not a naval exercise to constrain a particular enemy country, but an exercise in search and rescue operations and medical evacuation. Still, in terms of maritime security cooperation between ASEAN and China, it was undoubtedly a significant event.

\section{ASEAN's Policy toward the United States}

The United States is a "benign power" in the eyes of ASEAN (Haacke 2002, 13940). It has for decades maintained favorable relations with this association. To begin with, during the establishment process of ASEAN in the second half of the 1960s, the United States refrained from throwing its weight around in the capitals of the original members of this association. One of the regional security strategies Washington was considering at the time was to develop a new Southeast regional association into an anti-communist military organization, capable of contributing to its grand Cold War strategy in one way or another. It did not implement this strategy partly because it was aware of the tendency of the Southeast Asian nations to dislike external interference (Jo 2009, 208-14). Moreover, since the establishment of the association in 1967, the United States has contributed to the maintenance of regional security in Southeast Asia, mainly on a bilateral basis. Most notably, in the South China Sea, which is one of the busiest sea lines of 
communication in the world, it has safeguarded the freedom of navigation (FON) by using its enormous naval power. Since 2015, it has been carrying out a series of FON operations, partly intended to constrain Chinese activities there.

For a long time, the ASEAN members have heavily relied on this benign power for their national security. Thailand and the Philippines have maintained their military alliances with Washington for decades. Malaysia and Singapore have received substantial assistance from the United States since the Cold War era, despite their officially declared policy of non-alignment. Singapore in the post-Cold War era has been remarkably eager to cement its security relations with Washington. It has concluded a series of agreements with this global power to provide logistic support to US naval ships, make its military facilities available for the rotational deployment of U.S. naval ships, and host an area command of the U.S. navy, MSCFE (Military Sealift Command Far East). ${ }^{2}$

Unsurprisingly, ASEAN has always identified the maintenance of U.S. engagement in Southeast Asian security as one of its policy priorities, given its members' heavy reliance on Washington for their national security. This association has always been aware that a "benign power" can easily become capricious and concentrate on other regions because Southeast Asia is by no means high on the list of its strategic priorities. This is why ASEAN began holding regular meetings with the United States as early as 1977, invited Washington to the very first meeting of the PMC in 1979, and has made continuous efforts to strengthen its diplomatic ties with this global player to this day.

However, at the same time, ASEAN has cautiously avoided becoming overdependent on the United States. Without relying exclusively on one particular external power, it has sought to diversify its diplomatic partners, by building cooperative relations with various major players in the Asia-Pacific region and beyond. Especially since the 1990s, while not downplaying the value of its bilateral relations with Washington, it has placed importance on Asia-Pacific multilateralism. In 1993/94, it established its own Asia-Pacific region-wide framework, the ARF, and initiated in 2005 another region-wide framework at the summit level, the EAS. It has invited not only the United States but also various other major players-including China, Japan, South Korea, Australia, New Zealand, India, and Russia-to take part in these multilateral forums.

On the basis of these forums, ASEAN has not only been contributing to the construction of regional order in the Asia-Pacific region but also been increasing its own presence in this region. Since the 2000s, its presence has been conceptualized as "ASEAN's centrality" in Asia-Pacific multilateralism. This can be regarded as a remarkable achievement for an association of minor powers. Only by avoiding exclusive reliance on one particular external power, inviting various major players to take part in its own multilateral forums, and building cooperative relations with all of them, has such an association been able to claim itself as the center of Asia-Pacific multilateralism (Katsumata 2014). 


\section{ASEAN's Dealings with the BRI}

In what way has ASEAN dealt with the BRI? In other words, in what way has the Southeast Asian association taken up the major task of conducting equidistant diplomacy with China and the United States? In short, it has basically committed itself to the BRI; yet, at the same time, it has been careful not to overcommit itself. Thus, while keeping a certain distance from China, it has cleverly strengthened its economic and security relations with the United States. The present section discusses ASEAN's dealings with the BRI in detail.

\section{Committing to the BRI}

ASEAN has basically committed itself to the BRI, repeatedly expressing its support for Beijing's mega development initiative, partly for the sake of the implementation of its own regional development plan, entitled the Master Plan on ASEAN Connectivity 2025 (see ASEAN 2017; ASEAN and China 2019). Although China is a country which can easily pose a threat to regional security in Southeast Asia, the association of the nations there has responded positively to the Chinese initiative, and these nations collaborated with Beijing on a number of infrastructure development projects, with the aim of reaping as much benefit as possible from these projects. The BRI does offer the ASEAN members great opportunities to reap substantial benefits. Southeast Asia occupies an important strategic place within the BRI, and the nations there are effectively linking Beijing with more than fifty states located along the "maritime road," as noted earlier. While Southeast Asia is strategically important to China, the BRI is economically promising to the nations in this region.

For a fuller understanding of ASEAN's commitment to the BRI, it is worth focusing on the case of Singapore. This Southeast Asian city-state may seem less likely than most of the other ASEAN members to commit itself to China's initiative because, while enjoying strong security ties with Washington, it has less close relations with Beijing than most of the other members have (see Shambaugh $2018,100-03)$. It is worth restating, in this respect, that the BRI constitutes a core element of the geopolitical rivalry between China and the United States today. Nonetheless, Singapore has been an unabashed supporter of the BRI. Although it is sometimes manipulated by China's great diplomatic skills, it has never failed to make best efforts to maintain collaborative relations with Beijing.

To illustrate, China exercised skillful diplomacy vis-à-vis Singapore when it held the first Belt and Road Forum for International Cooperation in its capital city in May 2017. While inviting presidents and prime ministers from a number of countries to this forum, it did not send an invitation to the Singaporean Prime Minister Lee Hsien Loong, but to the Singaporean Development Minister Lawrence Wong. By so doing, it quietly expressed its dissatisfaction with Singaporean foreign policy. The city-state had been arbitrarily prioritizing its 
common interests with Washington at the expense of its relations with Beijing, from the viewpoint of the latter (see Tan 2017; Singapore Herald 2017).

Singapore responded to Chinese diplomacy promptly, and rushed to improve its relations with Beijing. In particular, in April 2018, it swiftly signed a memorandum of understanding with Beijing to facilitate collaboration between Singaporean and Chinese companies in third-party markets along the belt and road (Ministry of Trade and Industry of Singapore 2018a). On the basis of this memorandum, the Singaporean ministry of trade co-organized with its Chinese counterpart a BRI investment forum, involving about 300 business leaders from a wide range of sectors (Ministry of Trade and Industry of Singapore 2018b). It can be said that, given its position as the hub of a mega-regional trade network across the Indian Ocean and the Pacific Ocean, non-involvement in the BRI has never been an option for the Southeast Asian city-state.

\section{Avoiding Over-Commitment}

Although ASEAN has basically committed itself to the BRI, it has been careful not to overcommit itself, and therefore kept a certain distance from China. This kind of cautious attitude is comprehensible, in that over-commitment can easily result in overdependence, which inevitably gives Beijing opportunities to throw its weight around in Southeast Asia. One of the major concerns of the ASEAN members is to lose control over their own domestic infrastructure. When a country overcommits itself to an infrastructure development project of the BRI and falls behind in the payment of its debt, it may lose its rights to the infrastructure itself. The case of Sri Lanka is notable in this respect. This country was unable to pay off its debt, and ended up handing over the rights to its Hambantota Port to a Chinese governmental enterprise for a period of 99 years in December 2017. Sri Lanka may not be the only one, and some Southeast Asian nations may encounter similar problems because of their financial difficulties. In particular, Laos and Cambodia seem financially strapped. ${ }^{3}$ For any ASEAN member, a loss of control over its own domestic infrastructure is simply unacceptable, given its particular concern about external interference.

To be sure, ASEAN itself has never declared any intention of limiting the level of its commitment to the BRI, but the overall tendency of its members has clearly been to avoid over-commitment. This can be highlighted by focusing on Myanmar and Malaysia, both of which have already begun to limit their commitment to infrastructure development projects of the BRI, so as to mitigate the risk of debt distress. First, because of its very close ties with China, Myanmar may seem less likely than most of the other members to limit the level of its commitment. Nevertheless, in July 2018, it decided to scale down a port development project in its Kyaukpyu special economic zone, which is situated along the coast of the Bay of Bengal. This decision was a major blow to Beijing, given the economic potential of the Sino-Myanmar oil and natural gas pipelines 
running from Kyaukpyu to Kunming in the Yunnan province of China. Yet the decision was necessary for the Myanmar government, given the country's potential vulnerability to debt distress.

Second, Malaysia, whose position in the spectrum of the ASEAN members' closeness to China is roughly in the middle (see Shambaugh 2018, 100-03), cancelled in August 2018 a few large infrastructure development projects, including those for natural gas pipelines and a railroad connecting its capital city with its east coast cities. These projects had been major components of the BRI, and actively promoted by the former Prime Minister Najib Razak. When Mahathir Mohamad came back to power as a result of a general election in May 2018, fifteen years after stepping down as a prime minister, he decisively cancelled these projects, in order to minimize his country's financial risk. To be sure, in April 2019, he decided to restart the railroad project, but only after successfully negotiating with China to reduce its cost by more than 30 percent.

\section{Strengthening Relations with the United States}

While keeping a certain distance from China, ASEAN has cleverly strengthened its economic and security relations with the United States. This association has been particularly active on the economic front, so as to reap benefits from its relations with the United States while avoiding over-dependence on China. Thus, the recent development of its economic cooperation with Washington has been remarkable. In Manila in November 2017, ASEAN and the United States held a special meeting at the summit level to commemorate the fortieth anniversary of their institutionalized dialogue relations. The leaders at this meeting made sure that they would "support stronger economic engagement" between the two parties (ASEAN and the United States 2017).

Yet it should be mentioned that the development of economic cooperation between ASEAN and the United States is by no means a new phenomenon. Various achievements of their long-term economic cooperation were highlighted during the special meeting in Manila; for example, the ASEAN members together rank as the fourth largest export destination for U.S. companies and the fourth largest supplier of imports to the United States, with total two-way trade amounting to US\$211.8 billion in 2016 (ibid.). It is worth adding that, thus far, ASEAN has received around US $\$ 274$ billion in cumulative investment from the United States-an amount more than what the United States has directed to China, India, Japan, and South Korea combined (U.S.-ASEAN Business Council 2017).

Still, the recent development of economic cooperation between the two parties is indeed remarkable. For the further development of the ASEAN Economic Community, the Southeast Asian association has received various forms of assistance from Washington in recent years under the framework of the so-called "U.S.-ASEAN Connect," established by the U.S. government in 2016. 
Here critics may point out, by simply looking at the absolute amounts of money proposed at the official level, that the benefits ASEAN can expect to gain from Beijing's BRI are far greater than those from Washington's economic projects, including the U.S.-ASEAN Connect. However, it should be noted that, through its cooperative relations with Washington, ASEAN can expect to receive not only various forms of assistance from the U.S. government, but also large amounts of foreign direct investment from U.S. companies (Pitakdumrongkit 2018).

ASEAN has also been active on the security front. In order not to allow China to throw its geopolitical weight around in Southeast Asia and beyond via the "maritime road," this association has constantly put a premium on its longterm security cooperation with the United States. Notably, at its ministerial meeting with Washington in August 2018, it successfully elicited from this global player what can be regarded as a word of reassurance about its commitment to Southeast Asian regional security. At this meeting, the U.S. Secretary of State Michael Pompeo stated that his country is a "Pacific nation" which would "remain committed to ASEAN centrality under [its] Indo-Pacific strategy" (Pompeo 2018; also see Pence 2018). To be sure, this was not the first time and, even during the Cold War era, ASEAN often elicited words of reassurance from the United States. One of the essential purposes of ASEAN's PMC in the 1980s was to make sure, through the process of coordinating its policy toward the conflict in Cambodia with Washington's, that the United States would remain committed to Southeast Asian regional security. Nonetheless, what ASEAN elicited from the United States at the 2018 ministerial meeting was crucial, in that it was an reassurance from this global player in the context of its strategy in the Indo-Pacific, which has become the frontline of its rivalry with China today. Thereafter, premised on the U.S. commitment, defense cooperation between the two parties developed further, resulting in the first ASEAN-U.S. Maritime Exercise in September 2019.

Last but not least, ASEAN has cleverly strengthened its security relations not only with the United States but also with its allies such as Japan and the United Kingdom. To begin with, taking note of the "Vientiane Vision" issued by the Japanese government in 2016 (Ministry of Defense of Japan n.d.), this association has agreed to enhance its defense cooperation with Tokyo (ASEAN and Japan 2017), and supported several programs proposed by Japan to build the capacity of the Southeast Asian nations to deal with regional security challenges (Ministry of Defence of Singapore 2018a). On a yearly basis since 2017, for the purpose of capacity-building, ASEAN has been carrying out with Tokyo the ASEAN-Japan Ship Rider Cooperation Program (see Parameswaran 2019a).

In addition, some individual ASEAN members have taken measures to strengthen their security cooperation with the United Kingdom, thereby effectively diversifying their association's de facto security partners. While there have been several notable developments-for example, several defense meetings held between Vietnam and the United Kingdom in the last few 
years (Parameswaran 2019b) - the policy of Singapore is particularly notable. The city-state has maintained cooperative security relations with the United Kingdom for a long time, but taken a few additional measures to strengthen such relations even further in recent years. Most notably, in June 2018, it signed a memorandum of understanding with London, so as to broaden the scope of security cooperation between the two countries, to include new issues such as counter-terrorism, counter-improvised explosive devices, maritime security, and disaster relief (see Ministry of Defence of Singapore 2018b). By so doing, it has effectively highlighted the relevance of the Five Power Defence Arrangements (FPDA) to Southeast Asian regional security. Although the original purpose of the FPDA in 1971 was simply to tighten the security of Singapore and Malaysia, today this set of defense arrangements complements the existing regional security arrangements in Southeast Asia and beyond, including those centered on the United States (Emmers 2010).

\section{Conclusions}

In its dealings with the BRI, an association of minor powers in Southeast Asia has proactively advanced its own interests. It has done so by skillfully conducting equidistant diplomacy with China and the United States, without becoming too remote from or too close to either one of them, thereby reaping benefits from its favorable relations with each of them. The case of ASEAN testifies that minor powers are not always at the mercy of major powers. Today global geopolitical competition has become intense, as rising powers such as China, Russia, and Iran have been expanding their presence around the world, and challenging the existing international order established by the European and North American powers in the twentieth century (Mead 2014). Even under such circumstances, the Southeast Asian association has been successful in proactively advancing its own interests by its own means. Ultimately, it is not always true to say that the "more powerful...have more to say about which games will be played and how" (Waltz 1979, 194), and the "fortunes of all states... are determined primarily by the decisions and actions of those with the greatest capability" (Mearsheimer 2001, 5).

Both realists and constructivists who have written on ASEAN should pay serious attention to the findings of the present study, which highlights the diplomatic potential of this association. On the one hand, realists are usually pessimistic about ASEAN's ability, due to the insignificant military and economic capabilities of its members (see, for example, Leifer 1996; Jones and Smith 2007). On the other hand, constructivists tend to be more optimistic about its ability, yet their central concern is the promotion of its identity and norms in Southeast Asia and beyond (see, for example, Acharya 1998; 2014; Johnston 1999; 2008, Chap. 
4). Both of them should become aware of the fact that, in its dealings with the BRI, the Southeast Asian association has successfully advanced its own interests, without having significant material capabilities which satisfy realists and without exercising ideational entrepreneurship which excites constructivists. It can be said that the diplomacy of ASEAN not only brings tangible benefits to its members but also expands the frontiers of the knowledge of International Relations.

\section{Acknowledgements}

An earlier version of this article in Japanese was published in the December 2018 issue of Transportation \& Economy. An earlier draft of this article was presented at the International Studies Association (ISA) Annual Convention in Toronto on March 30, 2019. The authors thank the anonymous reviewers and participants at the ISA convention for their useful comments.

\section{Notes}

1. A few authors have argued that ASEAN members have maintained equidistant diplomatic relations with external powers. To illustrate, Evan Laksmana (2017) has used the notion of "pragmatic equidistance" to understand Indonesia's relations with both Beijing and Washington. Oh Ei Sun and David Han (2016) have argued that Malaysia has sought to build equidistant relations with both China and the United States.

2. Singapore signed with the United States a memorandum of understanding in 1990 to allow this global player to use its military facilities, a strategic framework agreement for a closer defense partnership in 2005, and an enhanced defense cooperation agreement as a new framework for defense cooperation in 2015 (see Ministry of Defence of Singapore 2005; Singapore and the United States 2015).

3. According to the Center for Global Development, among the sixty-eight countries which are identified as potential BRI borrowers, eight of them are at high risk of debt distress, and Laos is one of them. Fifteen of them are at some risk of debt distress. Cambodia is one of them and Sri Lanka is another (Hurley, Morris, and Portelance 2018).

\section{References}

Acharya, Amitav. 1998. "Collective Identity and Conflict Management in Southeast Asia." In Security Communities, edited by E. Adler and M. Barnett. Cambridge: Cambridge University Press, 198-227.

Acharya, Amitav. 2014. Constructing a Security Community in Southeast Asia: ASEAN and the Problem of Regional Order. London: Routledge.

ASEAN (Association of Southeast Asian Nations). 2017. "Chairman's Statement of the ASEAN Post-Ministerial Conference 10+1 Sessions with the Dialogue Partners." 
Manila, August 6.

ASEAN (Association of Southeast Asian Nations) and China. 2002a. "Declaration on the Conduct of Parties in the South China Sea." Phnom Penh, November 4.

ASEAN (Association of Southeast Asian Nations) and China. 2002b. "Framework Agreement on Comprehensive Economic Cooperation.” Phnom Penh, November 4.

ASEAN (Association of Southeast Asian Nations) and China. 2007. "Agreement on Trade in Services of the Framework Agreement on Comprehensive Economic Cooperation." Cebu, January 14.

ASEAN (Association of Southeast Asian Nations) and China. 2009. "Agreement on Investment of the Framework Agreement on Comprehensive Economic Cooperation." Bangkok, August 15.

ASEAN (Association of Southeast Asian Nations) and China. 2019. "ASEAN-China Ministerial Meeting." Bangkok, August 1.

ASEAN (Association of Southeast Asian Nations) and Japan. 2017. "Revised Implementation Plan of the Vision Statement on ASEAN-Japan Friendship and Cooperation: Shared Vision, Shared Identity, Shared Future." Manila, August 6.

ASEAN (Association of Southeast Asian Nations) and the United States. 2017. "Joint Statement of the ASEAN-US Commemorative Summit." Manila, November 13.

Chung, Chien-Peng. 2004. "Southeast Asia’s 'Hedging' Relationship with Major Powers of the Asia-Pacific." In Seeking Alternative Perspectives of Southeast Asia, eds. A. Tan, M. Smith, and K. K. Kim. Ipoh, Malaysia: Perak Academy, 287-317.

Emmers, Ralf. 2010. "The Role of the Five Power Defence Arrangements in the Southeast Asian Security Architecture.” Working Paper No. 195, S. Rajaratnam School of International Studies, April 20.

Goh, Evelyn. 2005. Meeting the China Challenge: The U.S. In Southeast Asian Regional Security Strategies, Policy Studies 16. Washington, D.C.: East-West Center Washington.

Gong, Xue. 2019. “The Belt \& Road Initiative and China's Influence in Southeast Asia." The Pacific Review 32 (4): 635-65.

Haacke, Jürgen. 2002. ASEAN's Diplomatic and Security Culture: Origins, Development and Prospects. London: Routledge.

Hurley, John, Scott Morris, and Gailyn Portelance. 2018. "Examining the Debt Implications of the Belt and Road Initiative from a Policy Perspective." CGD Policy Paper 121, Center for Global Development, March.

Jo, Yanghyeon. 2009. Ajia Chiiki-Shugi to America [Asian Regionalism and America]. Tokyo: University of Tokyo Press.

Johnston, Alastair Iain. 1999. "The Myth of the ASEAN Way? Explaining the Evolution of the ASEAN Regional Forum." In Imperfect Unions: Security Institutions over Time and Space, eds. H. Haftendorn, R. O. Keohane, and C. A. Wallander. Oxford: Oxford University Press, 287-324.

Johnston, Alastair Iain. 2008. Social States: China in International Institutions, 1980-2000. Princeton: Princeton University Press.

Jones, David Martin, and Michael L. R. Smith. 2007. "Making Process, Not Progress: ASEAN and the Evolving East Asian Regional Order." International Security 32 (1): 148-84.

Katsumata, Hiro. 2014. "What Explains ASEAN's Leadership in East Asian Community Building?” Pacific Affairs 87 (2): 247-64. 
Kliman, Daniel, and Abigail Grace. 2018. "Power Play: Addressing China’s Belt and Road Strategy." Center for a New American Security, September 20.

Kuik, Cheng-Chwee. 2016. "How Do Weaker States Hedge? Unpacking ASEAN States' Alignment Behavior Towards China." Journal of Contemporary China 25 (100): 50014.

Laksmana, Evan A. 2017. "Pragmatic Equidistance: How Indonesia Manages Its Great Power Relations." In China, the United States, and the Future of Southeast Asia, ed. D. B. H. Denoon. New York: NYU Press, 113-35.

Leifer, Michael. 1989. ASEAN and the Security of South-East Asia. London: Routledge.

Leifer, Michael. 1995. "ASEAN as a Model of a Security Community?" In ASEAN in a Challenged Regional and International Political Economy, ed. H. Soesastro. Jakarta: Center for Strategic and International Studies, 129-42.

Leifer, Michael. 1996. The ASEAN Regional Forum: Extending ASEAN's Model of Regional Security, Adelphi Paper No. 302. Oxford/London: Oxford University Press/ International Institute for Strategic Studies.

Li, Shipeng, and Dongchao Zheng. 2019. "BRI Links Nations, Does Not Lay 'Debt Traps.” China Daily, March 27.

Mead, Walter Russell. 2014. "The Return of Geopolitics: The Revenge of the Revisionist Powers." Foreign Affairs 93 (3): 69-79.

Mearsheimer, John J. 2001. The Tragedy of Great Power Politics. New York: W. W. Norton \& Company.

Ministry of Defence of Singapore. 2005. "Fact Sheet: The Strategic Framework Agreement." News Release, July 12.

Ministry of Defence of Singapore. 2018a. "ASEAN and Japan Plan to Step up Defense Cooperation." News Release, October 20.

Ministry of Defence of Singapore. 2018b. "Singapore and UK Strengthen Long-Standing Defence Ties for Next Bound.” News Release, June 2.

Ministry of Defense of Japan. n.d. "Vientiane Vision: Japan's Defense Cooperation Initiative with ASEAN.” Tokyo. https://www.mod.go.jp/e/d_act/exc/vientianevision (accessed August 21, 2019).

Ministry of Trade and Industry of Singapore. 2018a. "Memorandum of Understanding to Promote Greater Collaboration between Singapore and Chinese Companies." Press Release, April 8.

Ministry of Trade and Industry of Singapore. 2018b. "Ministry of Trade and Industry, Enterprise Singapore and National Development and Reform Commission Coorganize Inaugural Singapore-China Belt and Road Initiative Investment Forum in Singapore." Press Release, October 25.

Oh, Ei Sun, and David Han. 2016. "Malaysia’s Relations with the Major Powers: China and the United States.” Malaysia Update, S. Rajaratnam School of International Studies, March 1.

Parameswaran, Prashanth. 2019a. "Japan-ASEAN Indo-Pacific Security Cooperation in Focus with Ship Rider Program Launch.” The Diplomat, June 27.

Parameswaran, Prashanth. 2019b. "UK-Vietnam Military Ties in Focus with Defense Meeting." The Diplomat, April 2.

Pence, Michael R. 2018. "Remarks at the 2018 APEC CEO Summit." Port Moresby, Papua New Guinea, November 16. 
Pitakdumrongkit, Kaewkamol. 2018. “Indo-Pacific: US Role in Infrastructure.” RSIS Commentary (CO18132), S. Rajaratnam School of International Studies, August 6.

Pompeo, Michael R. 2018. "Remarks at the US-ASEAN Ministerial Meeting." Singapore, August 3.

Shabir, Sheikh. 2018. "Geopolitical and Economic Implications of the Belt and Road Initiative." The Geopolitics, July 1.

Shambaugh, David. 2018. "U.S.-China Rivalry in Southeast Asia: Power Shift or Competitive Coexistence?” International Security 42 (4): 85-127.

Singapore and the United States. 2015. "Joint Statement by US Secretary of Defense Ashton Carter and Singapore Minister for Defence Dr Ng Eng Hen.” December 7.

Singapore Herald. 2017. “China Confirms Lee Hsien Loong Deliberately Not Invited." May 18.

Strassler, Robert B., ed. 1996. The Landmark Thucydides: A Comprehensive Guide to the Peloponnesian War. New York: Free Press.

Tan, Jie Ying. 2017. "Why Is China Leaving Singapore out in the Cold?" ASEAN Today, June 3.

Tekdal, Veysel. 2018. "China’s Belt and Road Initiative: At the Crossroads of Challenges and Ambitions." The Pacific Review 31 (3): 373-90.

The Economist. 2018. "All under Heaven: China’s Belt-and-Road Plans Are to Be Welcomed - and Worried About." July 26.

U.S.-ASEAN Business Council. 2017. “Investment.” May 16. https://www.usasean.org/whyasean/investment (accessed September 27, 2018).

Waltz, Kenneth N. 1979. Theory of International Politics. New York: McGraw-Hill.

Wang, Yong. 2016. "Offensive for Defensive: The Belt and Road Initiative and China's New Grand Strategy." The Pacific Review 29 (3): 455-63.

Xi, Jinping. 2018. "Work Together for Common Development and a Shared Future." Keynote Speech at the Opening Ceremony of the 2018 Beijing Summit of the Forum on China-Africa Cooperation (FOCAC), September 3.

Zhang, Zhongyuan. 2019. "Belt and Road Initiative by No Means a Debt Trap." China Daily, Hong Kong Edition, March 3.

Hiro Katsumata is an Associate Professor at the Graduate School of International and Cultural Studies, Tohoku University, Japan. He specializes in ASEAN and Asia-Pacific regionalism.

Shingo Nagata is a Visiting Researcher at the Kanazawa University Graduate School of Human and Socio-Environmental Studies, Japan. He specializes in international security and the history of international relations of East Asia. 